\title{
Betwixt tormented hope and fear
}

else's job', the 'someone' is often, by default, the patient's GP. Onerous though this responsibility may be at times, some consolation may be obtained if it is seen as an opportunity to rage against the collusion of anonymity, investing capital in the 'mutual investment company' of doctor and patient.

The relationship between primary and secondary care, the subject of much of Balint's attention is perhaps all the more fraught today. He remarked that in the 1950s 'especially in London it is very seldom that the GP and consultant meet face to face'. ${ }^{3}$ With increasing demands on doctors in primary and secondary care, opportunities for contact across the divide are scarcer than ever.

Finally, given the vital nature of the doctor-patient relationship, it is perhaps surprising that so little emphasis is placed on its study in teaching and training. Many of the consultation models in use place great store in attempting to discover the patient's agenda, but there is not much reflection on the doctor-patient relationship. What if the patient does not wish to disclose their agenda today? How might they be best encouraged to make use of the drug 'doctor'? By reviving interest in the doctor-patient relationship, we might have the opportunity to disabuse the next generation of doctors of the concept of the 'heartsink', acting as 'touches on the tiller's in their patients' lives.

\section{Dan Edgcumbe}

\section{Further information}

Further information can be obtained through the Balint Society (www.balint.co.uk) which is open to all interested parties, and is willing to help in setting up new Balint groups. It runs several weekend events each year, produces the Journal of the Balint Society, and runs an annual essay competition. It is affiliated to the International Balint Federation which helps coordinate Balint activities throughout the world.

\section{REFERENCES}

1. Elder A, Oliver S. While I'm here, doctor. London: Tavistock, 1987.

2. Balint $\mathrm{E}$. The doctor, the patient and the group: Balint revisited. London: Routledge; 1993.

3. Balint M. The doctor, his patient and the illness. 2nd edn. Edinburgh: Churchill Livingstone, 1963.

4. Balint E, Norell JS. Six minutes for the patient: interactions in general practice. London: Tavistock; 1973.

5. Elder A, Oliver S. While I'm here, doctor. London: Tavistock, 1987.

DOI: 10.3399/bjgp10X539380
There has been much criticism of the promotion of GP commissioning in the recent White Paper on NHS reform, which seeks to give GPs a mediating role between patients as consumers and hospitals as corporate entrepreneurs. The role of business executive is unfamiliar and uncongenial to most GPs (although some relish the prospect of transcending the small shopkeeper traditions of British general practice). No doubt critics who point to the dangers of fragmentation and increased costs have a point.

But there has been much less attention to the associated theme of the White Paper, which is, in direct continuity with the approach of New Labour, to promote the public health role of GPs as managers of the lifestyles of their practice populations. There is an obvious contradiction between GPs' role as part priest, part policeman in manipulating the behaviour of patients in the contemporary crusades against drink and gluttony, promiscuity and idleness, and their role as tribunes of market forces and citizen empowerment. Both roles are corrosive of the relationship between the doctor as practitioner of scientific medicine and the patient seeking care and treatment for illness.

The enhanced public health role of GPs reflects both the decline of the political realm and the damaging erosion of boundaries between the public and personal spheres. Whereas politicians once advanced rival visions for the organisation of society from the perspective of major social movements, now they quibble over technical and administrative details and interfere in the intimate aspects of family and personal life. At the level of the individual, mere survival takes precedence over active engagement, as the cult of the body confirms.

An enfeebled sense of the scope for self-determination is associated with an intense preoccupation with the body and a heightened feeling of vulnerability to diverse environmental threats, whether real or imaginary. Hence there is a direct link between the inflation of health in modern society and contemporary forms of hypochondria and psychosomatic illness, a major and growing burden on individuals (causing illness and disability), on society (benefits) and on the health care system (over-investigation and inappropriate treatment).

In his study of 'hypochondriac lives' (recently re-published in paperback with an afterword on the tragic case of Michael Jackson), Brian Dillon nominates artist Andy Warhol as the personification of the tension between 'the temptation towards beauty and the certainty of decay'. Warhol's fears 'weight, complexion, age, aesthetics, the virulence of new diseases and the efficacy of the cures for old ones' - are 'emphatically our own'; he is our 'hypochondriac precursor." Dillon likens our current predicament to that of the melancholic in Robert Burton's classic 16th century account, who hovered anxiously 'tormented hope and fear betwixt'. ${ }^{2}$

Novelist Tim Parks writes with wit and insight about his personal quest for relief from chronic pelvic pain and lower urinary tract symptoms, for which no organic cause could be found and for which medical treatments were ineffective. This 'sceptic's search for health and healing', ${ }^{3}$ illuminated by literary digressions and philosophical reflections, ends in the discovery of Vipassana meditation, in 'sitting still, emptying the mind of self-regard, settling into your flesh and blood, soft breathing and long hours of just being there'. But although this retreat into ancient mysticism may have relieved the spasms of Parks' pelvic muscles, it cannot be regarded as a solution to the problems of diminished subjectivity in contemporary society. That requires the recovery of agency both individually and collectively and the restoration of the supremacy of the human mind and its potential over the inherent infirmities of the body.

\section{REFERENCES}

1. Dillon B. Tormented hope: nine hypochondriac lives. London: Penguin, 2009.

2. Burton R. Some anatomies of melancholy (Penguin Great Ideas). London: Penguin, 2008.

3. Tim Parks. Teach us to sit still: a sceptic's search for health and healing. London: Harvill Secker, 2010.

DOI: 10.3399/bjgp10X539399 